\title{
Farmers' Motivation on Water Apple Business in Wonosalam District, Demak Regency
}

\author{
Nur Rahmawati ${ }^{1 *}$, Febi Yogaswara ${ }^{1}$, Triyono ${ }^{1}$ \\ ${ }^{1}$ Agribusiness Department, Faculty of Agriculture, Universitas Muhammadiyah Yogyakarta, Indonesia \\ *Corresponding author. Email: rahma_wati_mf@umy.ac.id
}

\begin{abstract}
Low water apple productivity and less competitive prices are the problems faced by water apple farmers in Wonosalam District. However, with such a situation the farmers continue to cultivate water apple. In carrying out water apple farming, farmers have an effort and motivation. This research aims to describe the motivation of farmers in water apple farming and the factors related to the motivation of farmers in water apple farming. The method used is descriptive method. The research location was selected by purposive sampling and was carried out in Wonosalam District. The technique of determining respondents used the proportional random sampling method, taking 72 respondents of water apple farmers. Primary data were collected through observation and interviews with the help of a questionnaire. Meanwhile, the secondary data were obtained from the relevant authorities regarding the condition of the research area. The data analysis technique used is descriptive analysis and Spearman Rank Correlation. The results of the analysis show that the main motivation of farmers in carrying out water apple farming is to fulfill their basic needs, namely the fulfillment of physiological needs such as food, drink, clothing and shelter. The Spearman Rank correlation results show that internal factors (age, formal education, farming experience, land area, production, and income) have a significant relationship with existence needs, related needs, growth needs and motivation levels. Moreover, on the external factors, only the suitability of local culture has a significant relationship with the need for existence, related needs, and the level of motivation of farmers in water apple farming.
\end{abstract}

Keywords-existence, growth, water apple, farmer motivation, relatedness

\section{INTRODUCTION}

Water apple is a fruit plant originating from Southeast Asia, spread and found in Indonesia and Malaysia. Basically, water apple which is known and cultivated by the community is divided into two types, namely large water apple or sweet water apple (Syzygium samarangense) and small water apple or acidic water apple (Syzygium aqueum). Varieties of water apple which are classified as big water apple or sweet water apple are cincalo, wax, semarang, citra and pomegranate. Meanwhile, water apple varieties that are classified as water apple or acid water apple are button water apple[1]. Demak Regency is known as an area that is the center (area) for the production of water apple fruit in the province of Central Java[2]. This is due to the geographical location, climate and soil texture in Demak Regency in accordance with the requirements for growing water apple plants. The height of the land is at $0-1000$ meters above sea level (masl), the angle of the slope of the land is flat land and the soil texture is clay and loamy soil. There are two types of water apple that are cultivated by farmers in Demak Regency, namely the red pomegranate water apple variety and the image water apple variety. The production of water apple in Demak Regency in 2018 reached 78,249 quintals[3].
Table 1. Number of plants, production, and production average distribution of water apple in Demak Regency in 2018

\begin{tabular}{lcrr}
\hline \multicolumn{1}{c}{ Districts } & $\begin{array}{c}\text { Number } \\
\text { of Plants } \\
\text { (tree) }\end{array}$ & $\begin{array}{c}\text { Production } \\
\text { (kw) }\end{array}$ & $\begin{array}{r}\text { Production } \\
\text { Average } \\
\text { (kg / tree) }\end{array}$ \\
\hline Thunder & 15,484 & 13,854 & 152.39 \\
Sesame & 20,207 & 15,593 & 136.78 \\
Demak & 12,542 & 10,982 & 367.66 \\
Wonosalam & $\mathbf{3 4 , 2 7 4}$ & $\mathbf{1 1 , 1 2 0}$ & $\mathbf{7 3 . 6 9}$ \\
Attached & 10,668 & 6,192 & 135.23 \\
Bonang & 5,883 & 8,118 & 157.17 \\
Mranggen & 3,350 & 5,314 & 158.44 \\
Building & 6,037 & 3,655 & 150.78 \\
Karangtengah & 3,190 & 3,421 & 135.43 \\
\hline Demak Regency Agriculture Office, 2018 & \\
\hline
\end{tabular}

The production of water apple in Demak Regency is spread across several Districts, where the lowest average production in Wonosalam District. Based on Table 1, Wonosalam District has an average production of $73.69 \mathrm{~kg}$ / tree, has a number of plants of 34,274 trees and a production of 11,120 quintals. Seeing the distribution of water apple production in Demak Regency, Wonosalam District has a low level of productivity compared to other areas. Low productivity and less competitive water apple prices are a series of problems faced by farmers. This study aims to determine the motivation of water apple farming 
farmers, and to determine the factors related to farmer motivation.

\section{RESEARCH METHODS}

The basic method used is descriptive method. The location which is the object of research is in Wonosalam District, Demak Regency. The research location was determined purposively. The population in this study were 1,091 water apple farmers in Wonosalam District, Demak Regency, joined in 3 Gapoktan, namely 285 Sentosa Farmers (Kendaldoyong), 295 Sekar Tani farmers (Mranak), and 511 Sido Maju farmers (Sidomulyo). The technique of determining the respondents used was proportional random sampling method[4], by taking each of the farmer group association, namely 34 Sido Maju farmers, 20 Sekar Tani farmers and 18 Sentosa Farmers, so that the total respondents are 72 farmers.

The motivation of farmers in water apple farming is categorized into three, namely high, medium and low. To measure these categories, the following interval formula is used:

Interval $=\frac{\text { Lhighest score }-\sum \text { lowest score }}{\sum \text { category }}$

Table 2.. Category Level Of Each Need

\begin{tabular}{lccc}
\hline \multirow{2}{*}{ Needs } & \multicolumn{3}{c}{ Category } \\
\cline { 2 - 4 } & Low & Moderate & High \\
\hline Existence & $5,2-11,7$ & $11.8-18.3$ & $18.4-25$ \\
Relatedness & $4.1-9.3$ & $9.4-14.6$ & $14,7-20$ \\
Growth & $4.1-9.3$ & $9.4-14.6$ & $14,7-20$ \\
\hline
\end{tabular}

Measurement of the overall motivation level category is as follows:

Table 3. Motivation Level Category

\begin{tabular}{lc}
\hline Motivation Category & Score \\
\hline Low & $13-30.3$ \\
Moderate & $30.4-47.6$ \\
High & $47.7-65$ \\
\hline
\end{tabular}

To measure whether there is a relationship between motivation and internal factors and external factors, the Spearman Rank Coefficient is tested with the help of the SPSS 15.0 application using the following formula:

Information :

$$
r s=1 \frac{6 \Sigma d^{2}}{n\left(n^{2}-1\right)}
$$

rs = Spearman Rank Coefficient

$\mathrm{n} \quad=$ Number of samples

$\mathrm{d}=$ The difference in ranking obtained for each pair of observations

\section{RESULTS AND DISCUSSION}

\subsection{Characteristics of Water Apple Farmers}

Characteristics of water apple farmers in Wonosalam District were age, formal education, nonformal education, experience, land area, production, income, perceptions of the availability of capital assistance, perceptions of marketing, perceptions of land suitability, perceptions of local cultural suitability.

\subsubsection{Farmer Age}

Table 4. Age of water apple farmers in Wonosalam District

\begin{tabular}{ccc}
\hline Age (Years) & $\begin{array}{c}\text { Amount } \\
\text { (person) }\end{array}$ & Percentage (\%) \\
\hline $39-46$ & 17 & 23.61 \\
$\mathbf{4 7 - 5 4}$ & $\mathbf{2 2}$ & $\mathbf{3 0 . 5 6}$ \\
$55-62$ & 19 & 26.39 \\
$63-69$ & 14 & 19.44 \\
\hline Amount & $\mathbf{7 2}$ & $\mathbf{1 0 0}$ \\
\hline
\end{tabular}

Table 4, informs that the average age of water apple farmers is 54 years. This data shows that water apple farming is carried out by farmers of productive age so that they have high enthusiasm and good physical condition.

\subsubsection{Formal education}

Table 5. Formal Education for water apple Farmers in Wonosalam District

\begin{tabular}{lcc}
\hline Level of education & $\begin{array}{c}\text { Amount } \\
\text { (person) }\end{array}$ & Percentage (\%) \\
\hline SD & 41 & 56.9 \\
Junior High & 15 & 20.8 \\
High school & 15 & 20.8 \\
PT & 1 & 1.4 \\
\hline amount & $\mathbf{7 2}$ & $\mathbf{1 0 0}$ \\
\hline
\end{tabular}

Table 5, informs that the average level of formal education for farmers is primary school (SD). The data shows that water apple farmers in Wonosalam District have low awareness of the importance of education.

\section{Non-formal education}

Table 6. Non-formal Education for water apple Farmers in Wonosalam District

\begin{tabular}{ccc}
\hline Frequency & $\begin{array}{c}\text { Number of } \\
\text { (person) }\end{array}$ & $\begin{array}{c}\text { Percentage } \\
(\mathbf{\%})\end{array}$ \\
\hline $\begin{array}{c}\text { Counseling \& } \\
\text { Training }\end{array}$ & \\
0 & 46 & 63.89 \\
1 & 10 & 13.89 \\
2 & 8 & 11.11 \\
3 & 4 & 5,56 \\
4 & 3 & 4.17 \\
5 & 1 & 1.38 \\
\hline Total number & $\mathbf{7 2}$ & $\mathbf{1 0 0}$ \\
\hline \multicolumn{3}{c}{ Informs that the frequency of farmers participating } \\
in counseling and training & regarding water apple \\
farming ini Table 6 is relatively low. The average non- \\
formal education of water apple farmers in Wonosalam \\
District is 0.8 or only one time to attend counseling and \\
training while farming water apple
\end{tabular}




\subsubsection{Farming Experience}

Table 7. Farmers' Water apple Farming Experience in Wonosalam District

\begin{tabular}{ccc}
\hline $\begin{array}{c}\text { Experience } \\
\text { (Years) }\end{array}$ & $\begin{array}{c}\text { Amount } \\
\text { (person) }\end{array}$ & Percentage (\%) \\
\hline $4-8$ & 7 & 10 \\
$9-13$ & 28 & 39 \\
$14-18$ & 24 & 33 \\
$19-23$ & 8 & 11 \\
$24-28$ & 5 & 7 \\
\hline Amount & $\mathbf{7 2}$ & $\mathbf{1 0 0}$ \\
\hline
\end{tabular}

Table 7 , informs that the average experience of farmers in implementing water apple farming is 14 years. These data indicate that farmers have sufficient experience to manage water apple farming.

\subsubsection{Land area}

Table 8. Farmers' Land Area in water apple Farming in Wonosalam District

\begin{tabular}{ccc}
\hline Land Size $\left(\mathbf{M}^{2}\right)$ & $\begin{array}{c}\text { Amount } \\
\text { (person) }\end{array}$ & Percentage (\%) \\
\hline $30-4000$ & 62 & 86.11 \\
$5000-8,000$ & 7 & 9.72 \\
$9,000-12,000$ & 2 & 2.78 \\
$13,000-20,000$ & 1 & 1.39 \\
\hline Total number & $\mathbf{7 2}$ & $\mathbf{1 0 0}$ \\
\hline
\end{tabular}

Table 8, informs that land area used by farmers for water apple farming ranges from $30-20,000 \mathrm{~m} 2$. The average land area for farmers in Wonosalam District is $2,232 \mathrm{~m} 2$.

\subsubsection{Production}

Table 9. Results of Water apple Production in Wonosalam District in 2018

\begin{tabular}{ccc}
\hline Production (Kg) & $\begin{array}{c}\text { Amount } \\
\text { (person) }\end{array}$ & Percentage (\%) \\
\hline $52-3500$ & 37 & 51 \\
$3600-7000$ & 18 & 25 \\
$7,100-10,500$ & 10 & 14 \\
$10,500-14,000$ & 7 & 10 \\
\hline Total number & $\mathbf{7 2}$ & $\mathbf{1 0 0}$ \\
\hline
\end{tabular}

Table 9, informs that the largest water apple production in Wonosalam District is $14,000 \mathrm{~kg}$ and the smallest is $52 \mathrm{~kg}$. As for the average yield of water apple production is $4,491 \mathrm{~kg}$ and the productivity of the tree is $92 \mathrm{~kg} /$ tree.

\subsubsection{Income}

Table 10. Income of Water Apple in Wonosalam District in 2018

\begin{tabular}{ccc}
\hline Income $(\mathbf{R p})$ & $\begin{array}{c}\text { Amount } \\
(\text { Soul })\end{array}$ & $\begin{array}{c}\text { Percentage } \\
(\boldsymbol{\%})\end{array}$ \\
\hline $509,000-45,000,000$ & 50 & 69 \\
$46,000,000-91,000,000$ & 15 & 21 \\
$92,000,000-137,000,000$ & 5 & 7 \\
$138,000,000-184,000,000$ & 2 & 3 \\
\hline Total number & $\mathbf{7 2}$ & $\mathbf{1 0 0}$ \\
\hline
\end{tabular}

Table 10, informs that the average income of water apple farming is Rp. 49,049,000/year or three harvest seasons, the nominal amount is higher than the Minimum Wage in Demak Regency which is $\mathrm{Rp}$. 26,880,000 per year (Rp. 2,240,000 per month).

\subsubsection{Perception of Availability of Capital Assistance}

Table 11. Perceptions of water apple Farmers on Availability of Capital Assistance in Wonosalam District

\begin{tabular}{clc}
\hline No. & \multicolumn{1}{c}{ Indicator } & Score \\
\hline 1 & $\begin{array}{l}\text { Get help from the government } \\
2\end{array}$ & $\begin{array}{l}\text { Get facilitation assistance from farmer } \\
\text { groups }\end{array}$ \\
\hline & Average & 2.01 \\
\hline & Category & $\mathbf{2 . 2 9}$ \\
\hline
\end{tabular}

Table 11, informs that the availability of capital assistance earned a score of 2.29, it is in the low category. Based on the results of interviews, farmers assumed that they still rarely received direct funding assistance or inputs from the government and even if there was, they had difficulty differentiating the sources of assistance. Then the farmers also still do not understand the working system of the farmer groups, for example in terms of lending supporting facilities for water apple cultivation, such as pest control sprays. Farmers consider that these facilities must be private property.

\subsubsection{Perceptions of Marketing}

Table 12. Perceptions of water apple Farmers on Marketing of water apple Products in Wonosalam District

\begin{tabular}{clcc}
\hline No. & \multicolumn{1}{c}{ Indicator } & Score \\
\hline 1 & $\begin{array}{l}\text { The yields of water apple are easy to sell or } \\
\text { market }\end{array}$ & 4.51 \\
2 & $\begin{array}{l}\text { Buying and selling systems and easy } \\
\text { payments }\end{array}$ & 3.96 \\
\hline & Average & $\mathbf{4 . 2 4}$ \\
\hline Category & High \\
\hline
\end{tabular}

Table 12, informs that marketing gets a score of 4.24 , in the high category. Based on the results of the interview, the farmers thought that thewater apple harvest was easy to sell because there were many collectors accommodating their harvest. Farmers also consider that the buying and selling system is fairly easy because the cashew harvest is delivered by farmers to collectors and vice versa. In addition, the payment system is fairly easy because it is paid directly (cash) during the buying and selling process. 


\subsubsection{Farming Risk}

Table 13. Perceptions of water apple Farmers on Risks of water apple Farming in Wonosalam District

\begin{tabular}{clc}
\hline No. & \multicolumn{1}{c}{ Indicator } & Score \\
\hline 1 & $\begin{array}{l}\text { Water apple plants are often attacked by } \\
\text { pests }\end{array}$ & 3.96 \\
2 & The yield of water apple is easy to rot & 3.43 \\
\hline & Average & $\mathbf{3 , 7}$ \\
\hline & Category & High \\
\hline
\end{tabular}

Table 13, informs that the risk of farming obtains a score of 3.7, and is in the high category. Based on the results of interviews, farmers assumed that plants were often attacked by pests, namely pagoda caterpillars, flies and bats. Furthermore, the results of the water apple harvest are also easy to rot, this is caused by mistakes made in the picking, sorting and packing processes.

\subsubsection{Suitability of Land Potential}

Table 14. Perceptions of Farmers on the Suitability of Land Potential in Wonosalam District

\begin{tabular}{clc}
\hline No. & \multicolumn{1}{c}{ Indicator } & Score \\
\hline 1 & The climate is suitable for water apple & 4.08 \\
2 & Land suitable for water apple & 4.07 \\
\hline & Average & $\mathbf{4 . 0 8}$ \\
\hline Category & High \\
\hline
\end{tabular}

Table 14, informs that the land potential suitability obtained a score of 4.08 , which is included in the high category. Based on the results of interviews, farmers think that the climate and land in Wonosalam District are suitable for carrying out water apple farming because the altitude is at 0-100 masl with temperatures ranging from $28^{\circ}-34^{\circ} \mathrm{C}$, the soil type is fertile and loose and is on flat land with $\mathrm{pH}$ 6-7.5, which is in accordance with the requirements for growing water apple plants.

\subsubsection{Perceptions of Local Cultural Appropriateness}

Table 15. Perceptions of water apple Farmers on the Appropriateness of Local Culture in Wonosalam District

\begin{tabular}{clc}
\hline No. & \multicolumn{1}{c}{ Indicator } & Score \\
\hline \multirow{2}{*}{1} & Water apple has been planted for a long & 4.26 \\
2 & time & 3.93 \\
\hline & People like water apple & $\mathbf{4 . 1 0}$ \\
\hline & Average & High \\
\hline
\end{tabular}

Table 29, informs that the suitability of local culture scores 4.10 is in the high category. Based on the results of the interview, farmers think that the water apple farming in Wonosalam District has been around for a long time and has become a hereditary farming. In addition, water apple is also very popular with the local community, water apple is the main fruit consumed by the community and is usually processed into sweets, juice, syrup and lunched

\subsection{Motivation of water apple Farmers}

\subsubsection{Need for Existence}

Table 16. Perceptions of Farmers on the Need for Existence (Existence)

\begin{tabular}{clcc}
\hline No. & \multicolumn{1}{c}{ Indicator } & $\begin{array}{c}\text { Score } \\
\text { Range }\end{array}$ & Score \\
\hline 1 & $\begin{array}{l}\text { Fulfilling family food needs } \\
\text { (eating and drinking) }\end{array}$ & 4.14 \\
2 & $\begin{array}{l}\text { Meet the needs of clothing and } \\
\text { shelter (clothing and shelter) }\end{array}$ & 3.88 \\
3 & $\begin{array}{l}\text { Meet sudden needs (health) } \\
4\end{array}$ & $\begin{array}{l}\text { Meet the needs of the cost of } \\
\text { education }\end{array}$ \\
5 & $\begin{array}{l}\text { Meeting needs is valued and } \\
\text { respected by others }\end{array}$ & 3.39 \\
\hline \multicolumn{2}{c}{ Amount } & 3.81 \\
\hline \multicolumn{2}{c}{ Category } & $\mathbf{1 8 . 9}$ \\
\hline
\end{tabular}

Table 16, informs that in general the need (existence) of water apple farmers in Wonosalam District is in the high category with a score of 18.9. Based on the results of the interviews, the farmers admitted that the results of the water apple farming were sufficient to meet the normal food needs of their families, namely three times a day. The results of water apple farming are also sufficient to meet the needs of school uniforms and nonformal clothes for daily activities, especially for nonformal ones, which are usually purchased during Eid alFitr. The results of water apple farming are also able to send their children to the college and police academy levels. However, regarding the funds to meet the health needs of farmers, it is not particularly prepared. The results of cultivation of water apple are also sometimes able to improve the conditions of their living such as wall plaster and wall painting. Farmers also feel that the relationship between residents or neighbors has become more harmonious because they can exchange information about water apple cultivation.

\subsubsection{Need to Connect (Relatedness)}

Table 17.Water apple Farmers' Perceptions of the Need for Relationship (Relatedness)

\begin{tabular}{|c|c|c|c|}
\hline No. & Indicator & $\begin{array}{l}\text { Score } \\
\text { Range }\end{array}$ & Score \\
\hline 1 & $\begin{array}{l}\text { Often interacts with } \\
\text { fellowwater apple farmers }\end{array}$ & \multirow{4}{*}{$1-5$} & 3.94 \\
\hline 2 & $\begin{array}{l}\text { Adding and expanding } \\
\text { relationships with farmer } \\
\text { groups }\end{array}$ & & 3.76 \\
\hline 3 & $\begin{array}{l}\text { Opening up opportunities to } \\
\text { cooperate with collectors, } \\
\text { traders and processing } \\
\text { industries }\end{array}$ & & 3.44 \\
\hline 4 & $\begin{array}{l}\text { Strengthening social relations } \\
\text { with the surrounding } \\
\text { community }\end{array}$ & & 3.57 \\
\hline & Amount & & 14.72 \\
\hline & Category & & High \\
\hline
\end{tabular}


Table 17, informs that in general the needs (relatedness) of water apple farmers in Wonosalam District are in the high category with a score of 14.72 . Based on the results of interviews in the field, farmers interacted more frequently with other water apple farmers, the interactions carried out were in the form of sharing ways of handling plant pests (OPT), ways to increase production, to discussing uncertain water apple price fluctuations. Farmers also have an interest in activities in farmer groups such as discussions, providing input for production inputs, counseling and training. Cultivating water apple also opens opportunities for farmers to collaborate with collectors, traders and processing industries. Collectors and traders become places for farmers to sell their crops, farmers still find it difficult to sell their crops to the processed industry because there is only one "UMKM Restu Wali". Farmers also feel they have the same social status as the surrounding community because almost all of the surrounding communities carry out water apple farming as well.

\subsubsection{The Need for Growth}

Table 18. Perceptions of water apple Farmers on the Need for Growth (Growth)

\begin{tabular}{|c|c|c|c|}
\hline No. & Indicator & $\begin{array}{l}\text { Score } \\
\text { Range }\end{array}$ & Score \\
\hline 1 & $\begin{array}{l}\text { Able to buy tertiary items } \\
\text { (jewelry, vehicles) }\end{array}$ & \multirow{4}{*}{$1-5$} & 3.33 \\
\hline 2 & $\begin{array}{l}\text { Increase knowledge of } \\
\text { cultivating } \quad \text { water apple } \\
\text { (pesticides, seeds, fertilizers) }\end{array}$ & & 4.01 \\
\hline 3 & $\begin{array}{l}\text { Improve skills in cultivating } \\
\text { water apple (planting, caring } \\
\text { for and harvesting) }\end{array}$ & & 4.15 \\
\hline 4 & $\begin{array}{l}\text { Fulfilled for new venture } \\
\text { capital }\end{array}$ & & 3.71 \\
\hline & amount & & 15.21 \\
\hline & Category & & High \\
\hline
\end{tabular}

Table 18, informs that in general the need (growth) of water apple farmers in Wonosalam District is in the high category with a score of 15.21. Based on the results of interviews in the field, the farmers admitted that sometimes the cashew fruit farming was enough to buy vehicles and jewelry. Farmers also admit that their knowledge and skills in running the farmers' water apple farming have increased. For example, farmers know the seeds that meet the requirements for planting, the type and use of fertilizers for water apple plants and the right time to spray pesticides. So far, in an effort to improve the knowledge and skills of water apple farming, the farmers have absorbed information and experiences from farmers who had previously been water apple farmers. The information on extension and training activities from the government has not reached all water apple farmers. In addition, the results of water apple farming are sometimes used as additional capital to develop a larger scale of water apple farming.

\subsection{Motivation Level of water apple Farmers}

Based on the details of the discussion on indicators of the motivation needs of water apple farmers' existence, relatedness and growth can be seen how big the motivation level of water apple farmers in Wonosalam District.

Table 19. Motivation Level

\begin{tabular}{lccc}
\hline \multicolumn{1}{c}{ Needs } & Score Range & Score & Percentage \\
\hline Existence & $5-25$ & 18.92 & $29 \%$ \\
Relatedness & $4-20$ & 14.72 & $23 \%$ \\
Growth & $4-20$ & 15.21 & $24 \%$ \\
\hline amount & $\mathbf{4 8 . 8 5}$ & $\mathbf{7 6 \%}$ \\
\hline Category & High \\
\hline
\end{tabular}

Table 19, informs that the overall motivation level of water apple farmers in Wonosalam District is in the high category with a score of 48.85 with a percentage of $76 \%$. The indicator that gets the highest score is existence with a score of 18.92 with a percentage of $29 \%$, then followed by growth with a score of 15.21 with a percentage of $24 \%$, and the last is relatedness with a score of 14.72 with a percentage. 23\%. This means that the main motivation of farmers in carrying out-water apple farming is to meet physiological needs such as food, drink, clothing and shelter. As for the background relatedness needs are lower than other needs because relatedness needs originate from outside the farmer who cannot control them, for example there is still a lack of MSMEs that can be used as partners in terms of distributing water apple crops so that farmers only sell their crops to collectors and merchants around the house only. This is different from research on the motivation of farmers in rice farming in Simo District, Boyolali Regency, which shows that the needs of rice farmers who get high scores are relatedness needs and existence needs. Meanwhile, growth needs get a low score. This means that there are differences between water apple farmers and rice farmers in meeting their main needs. [5]

\subsection{Factors Related to Motivation}

To determine the relationship of these factors to the level of motivation used the Spearman Rank Correlation Test with the help of SPSS 15.0. The results of the analysis of the relationship between these factors will be explained as follows.

\subsubsection{Internal factors}

Table 20. The results of the Spearman Rank Correlation analysis of internal factors related to the motivation of water apple farmers.

\begin{tabular}{llllll}
\hline \multicolumn{1}{c}{ Variable } & \multicolumn{5}{c}{ Existence RelatednessGrowthMotivation } \\
\hline \multirow{2}{*}{ Age } & Koef & $0.365 * * *$ & 0.120 & 0.078 & $0.266 * *$ \\
\multirow{2}{*}{ Formal education } & Sig & 0.002 & 0.315 & 0.515 & 0.024 \\
& Koef & $-0,204 *$ & -0.014 & $-0,115$ & -0.175
\end{tabular}




\begin{tabular}{|c|c|c|c|c|c|}
\hline \multirow[t]{2}{*}{ Variable } & & \multicolumn{4}{|c|}{ Existence RelatednessGrowthMotivation } \\
\hline & Sig & 0.086 & 0.910 & 0.337 & 0.141 \\
\hline \multirow{2}{*}{ Non-formal educatio } & Koef & 0.064 & 0.096 & 0.103 & 0.098 \\
\hline & Sig & 0.595 & 0.424 & 0.389 & 0.412 \\
\hline \multirow{2}{*}{ Farming Experience } & Koef & 0.008 & $0.371 * * *$ & $\begin{array}{l}-0,224 \\
*\end{array}$ & 0.015 \\
\hline & Sig & 0.948 & 0.001 & 0.059 & 0.902 \\
\hline \multirow{2}{*}{ Land area } & Koef & $0.367 * * *$ & -0.052 & $\begin{array}{l}0.528 \\
* * *\end{array}$ & $0.420 * * *$ \\
\hline & Sig & 0.002 & 0.665 & 0,000 & 0,000 \\
\hline \multirow{2}{*}{ Production } & Koef & $0.499 * * *$ & 0.145 & $\begin{array}{l}-0.376 \\
* * *\end{array}$ & $0.466 * * *$ \\
\hline & Sig & 0,000 & 0.225 & 0.001 & 0,000 \\
\hline \multirow[t]{2}{*}{ Income } & Koef & $0.548 * * *$ & $0.217 *$ & $\begin{array}{l}0.447 \\
* * *\end{array}$ & $0.551 * * *$ \\
\hline & $\mathrm{Sig}$ & 0,000 & 0.068 & 0,000 & 0,000 \\
\hline Information: & $\begin{array}{l}* * * * \\
* * \\
*\end{array}$ & $\begin{array}{l}\text { Sign } \\
\text { Sign } \\
\text { Sign }\end{array}$ & $\begin{array}{l}\text { ificant at } \\
\text { lificant at } \\
\text { ificant at }\end{array}$ & $\begin{array}{l}\alpha=10 \\
\alpha=50 \\
\alpha=10\end{array}$ & \\
\hline
\end{tabular}

Age

Based on the test results, age has a positive and significant relationship with the need for existence and the level of motivation is at the $99 \%$ and $95 \%$ confidence levels. The increasing age of farmers, the higher the need for farmer existence. Based on the results of research in the field, the average age of water apple farmers in Wonosalam District is 54 years old or classified as productive age. Farmers of productive age generally have families so that they have more dependents in terms of meeting their basic needs (clothing, food, shelter). This is in line with research [6] about the motivation of farmers in realizing household food security of rice farmers in Jatiragas Hilir Village, Subang Regency, who wrote that age in his research was classified as productive and had a significant relationship with farmer motivation. In addition, in a research Makalew wrote that the higher the farmer's age, the higher the farmer's motivation and vice versa.

\section{Formal education}

Based on the test results, formal education has a negative and significant relationship with the need for existence at a $90 \%$ confidence level. The higher the farmer's formal education, the lower the farmer's existence needs. Based on the results of research in the field, farmers with higher education did not make water apple farming their main job. There are farmers with high levels of education who become teachers, village heads and village officials. This is different from Hendarto's research [7] regarding factors related to the level of motivation of oil palm farmers in repaying credit in Srikonton Village, Bengkulu Regency, who wrote that formal education in his research did not have a significant relationship with the motivation of oil palm farmers.

\section{Non-formal education}

Because non-formal education has no significant relationship with the needs for existence, relatedness, growth and motivation level of water apple farmers in Wonosalam District, non-formal education can be categorized as a factor that can be ignored. This is different from the research of Badhan (2017).[8] about the motivation in sunflower cultivation which shows that the pbadhanelatih activities that are followed by most of the farmers are in the medium category, which is 4-6 times. Training has an influence on farmers in running their farming, because training helps farmers to understand and determine useful techniques for their farming. Furthermore, in Obaniyi's research [9] wrote also that extension activities in his research had an influence on the level of motivation of farmers.

\section{Farming Experience}

Based on the results, farming experience has a positive and significant relationship with relatedness needs and a negative relationship with growth needs at the $99 \%$ and $90 \%$ confidence levels. The longer the farming experience period, the higher the farmer's relatedness needs, while the shorter the farming experience period, the higher the farmer's growth needs. Based on the results of research in the field, water apple farmer experience period is quite long (14 years) so that the farmers have a broad and close connection with collectors and traders. In addition, farmers whose farming experience is below 10 years have a higher desire to increase their knowledge and skills to run their farms, usually they often ask questions and ask for advice from farmers who have been farmers for a long time. This is in line with Aprillia's (2018) research on farmer motivation in realizing household food security of rice farmers in Jatiragas Hilir Village, Subang Regency, who wrote that farming experience in his research has a significant relationship with the level of farmer motivation. Furthermore in research (Makalew, 2013)[10] wrote also that the higher farming experience of farmers will increase their knowledge (knowing appropriate fertilizers) and farmer skills in farming.

\section{Land area}

Based on the results, land area has a positive and significant relationship with the needs for existence, growth and motivation level at the $99 \%$ confidence level. The wider the farmer's land, the higher the need for existence, growth and farmer motivation level. Based on the results of research in the field, farmers with a larger land area get higher production and income. This is also in line with research [5] about the motivation of farmers to cultivate rice in Gunung Village, Boyolali Regency, who wrote that the land area has a significant relationship with the farmer's existence needs. In addition, farmers whose land area is larger have a desire to improve their knowledge and skills in implementing their water apple farming for the better by asking farmers who are more successful and following counseling and training conducted by BPP. The average land area for water apple farmers in Wonosalam District is 2,232 M2 (quite large). This is also in line with research [6] about the motivation of farmers in realizing 
household food security of rice farmers in the village of Jatiragas Hilir, Subang Regency, wrote that land area has a significant relationship with farmer motivation.

\section{Production}

Based on the results, production has a positive and significant relationship with the need for existence and the level of motivation as well as a negative relationship with the need for growth at the $99 \%$ confidence level. The higher the production, the higher the need for existence and motivation level of farmers. Based on the results of research in the production field obtained by water apple farmers in Wonosalam District, namely 52 $\mathrm{kg}-14,000 \mathrm{~kg} /$ year with an average of $4.491 \mathrm{~kg}$, with an average production yield of $4,491 \mathrm{~kg}$, the average farmer income is Rp. 49,049,000 / year. In addition, farmers whose production is low usually ask other farmers with high water apple production how to increase their water apple production.

\section{Income}

Based on the results, income has a positive and significant relationship with the needs of existence, relatedness, growth and the level of motivation with a confidence level of $99 \%$ and $90 \%$. The higher the income, the higher the need for existence, relatedness, growth and farmer motivation level. Based on the results of research in the field the average income of farmers is Rp. 49,049,000 / year. The high income is sufficient to meet the basic food needs of his family three times a day, send his children to college and can renovate his house. This is also in line with Dewi's (2016) research on the motivation of farmers to cultivate rice in Gunung Village, Boyolali Regency, which states that income has a significant relationship with the farmers' need for existence. Other than that, To sell their crops, farmers with high income have more than one collector and regular trader. Even farmers with high income can afford to buy vehicles (motorbikes) and jewelry. This is in line with Nurdina's (2015) research.[11] Regarding the motivation of farmers in managing community forests in Sukoharja Village, Pringsewu District, he wrote that income has a significant relationship with farmer motivation. The higher the farmer's income, the higher the farmer's motivation.

\subsubsection{External Factors}

Table 21. The results of the Spearman Rank Correlation analysis of external factors related to the motivation of water apple farmers.

\begin{tabular}{llrrrr}
\hline \multicolumn{1}{c}{ Variable } & & Existence & $\begin{array}{c}\text { Related } \\
\text { ness }\end{array}$ & Growth & $\begin{array}{c}\text { Motivati } \\
\text { on }\end{array}$ \\
\hline Availability & Koef & 0.060 & 0.055 & -0.035 & 0,000 \\
of Capital & Sig & 0.661 & 0.647 & 0.768 & 0.997 \\
Assistance & Koef & 0.053 & -0.020 & 0.017 & 0.020 \\
Marketing & Sig & 0.661 & 0.993 & 0.887 & 0.868 \\
& Koef & -0.018 & -0.087 & -0.101 & -0.096 \\
Farming Risk & Sig & 0.882 & 0.469 & 0.397 & 0.420
\end{tabular}

\begin{tabular}{llrrrr}
\hline \multicolumn{1}{c}{ Variable } & & Existence & $\begin{array}{c}\text { Related } \\
\text { ness }\end{array}$ & Growth & $\begin{array}{c}\text { Motivati } \\
\text { on }\end{array}$ \\
\hline $\begin{array}{l}\text { Suitability of } \\
\text { Land }\end{array}$ & Koef & -0.193 & -0.099 & -0.057 & -0.157 \\
$\begin{array}{l}\text { Potential } \\
\text { Local }\end{array}$ & Sig & 0.140 & 0.410 & 0.634 & 0.187 \\
$\begin{array}{l}\text { Cultural } \\
\begin{array}{l}\text { Appropriaten } \\
\text { ess }\end{array}\end{array}$ & Koef & $-0.253 * *$ & $\begin{array}{r}-0,206 \\
*\end{array}$ & -0.193 & $-0.261 * *$ \\
Information: & $* *$ & 0.032 & 0.082 & 0.105 & 0.027 \\
\hline & $*$ & \multicolumn{5}{c}{$\begin{array}{l}\text { Significant at } \alpha=5 \% \\
\text { Significant at } \alpha=10 \%\end{array}$}
\end{tabular}

Factors that are significantly related to the need for existence, relatedness, growth and motivation level of water apple farmers in Wonosalam District are farmers' perceptions of local cultural suitability, while farmers' perceptions of the availability of capital assistance, farmers' perceptions of marketing, farmers' perceptions of farming risks, farmers' conformity Land potential has no significant relationship to the needs of existence, relatedness, growth and motivation level of water apple farmers in Wonosalam District.

Based on the test results, farmers' perceptions of the suitability of local culture have a negative and significant relationship with the needs for existence, relatedness, and motivation levels at the $95 \%$ and $90 \%$ confidence levels. The lower the suitability of local culture, the higher the need for existence, relatedness and motivation level of farmers. Moreover, water apple farmers in Wonosalam District could cultivate another commodities such as rice and star fruit to fulfill their basic needs. In addition, in their daily lives, farmers keep in touch and interact with the surrounding community to carry out social activities in general. Water apple farming is accordance with the local culture because water apple farming is a hereditary farming.

\section{CONCLUSION}

The main motivation of farmers in carrying out water apple farming is to fulfill their basic needs, including fulfillment of physiological needs such as food, drink, clothing and shelter. Internal factors that have a significant relationship with existence, relatedness, growth and level of motivation are age, formal education, farming experience, land area, production and income. External factors that have a significant relationship with the existence, relatedness and motivation level of farmers' in water apple farming are the suitability of local culture. Meanwhile, the factors that do not have a significant relationship with the needs of existence, relatedness, growth and the level of motivation of farmers are non-formal education, availability of capital assistance, marketing, farming risks and suitability of land potential.

\section{REFERENCES}

[1] MB Sibuea, M. Thamrin, and J. Tarigan, "Study of Marketing Efficiency of Apple King Rose Water apple," J. Agrium, vol. 18, no. 2, pp. 162-168, 2013. 
[2] R. Setiarini, "Factors Affecting the Production of water apple Water in Wonosari Village, Demak Regency," Econ. Dev. Anal. J., vol. 2, no. 4, pp. 446-455, 2013.

[3] Demak Regency Agriculture Office. (2019). Production of Water apple in Demak Regency 2018. Demak.

[4] Sugiyono, Business Research Methods. Bandung: Alfabeta, 2017.

[5] MM Dewi, BW Utami, and H. Ihsaniyat, "The Motivation of Rice Farmers (Case in Gunung Village, Simo District, Boyolali Regency)," J. Agista, vol. 4, no. 3, pp. 104-114, 2016.

[6] E. Aprilia, R. Andriani, and B. Kusumo, "Farmers' Motivation in Achieving Household Food Security of Rice Paddy Farmers in Jatiragas Hilir Village, Patok Besi Subdistrict, Subang Regency," J. Ilm. Mhs. AGROINFO GALUH, vol. 4, no. 3, pp. 819827, 2018, doi: 10.1017 / CBO9781107415324.004.

[7] R. Hendarto, Badrudin and MZ Yuliarso, "Factors Related To The Motivation of Palm Oil Farmers To Pay Back Their Loan in Baitul Maal Watamwil Cooperative Srikaton Village Pondok Kelapa," AGRISEP Vol. 11 No. March 1, 2012 Pages 22 34, vol. 11, no. 1, pp. 22-34, 2012.
[8] A. Badhan, M. Akanda, and A. Haque, "Farmer's Level Motivation on Sunflower Cultivation in a Rice Based Cropping Pattern of Patuakhali District," Asian J. Agric. Extension, Econ. Sociol., vol. 18, no. 2, pp. 1-11, 2017, doi: 10.9734 / ajaees / 2017/33503.

[9] KS Obaniyi, JA Akangbe, BM Matanmi, and GB Adesiji, "Factors motivating incentives of farmers in rice Production training programs (A case study of Olam / USAID / ADP / First Bank Program)," WebPub J. Agric. Res., vol. 2, no. May, pp. 74-81, 2014.

[10] J. Makalew, Z. Kusuma, Sugiarto, and Z. Tamod, "The Influence of Farmer Characteristic and Farming to the $\backslash$ nFarmer Motivation on Using Organic Manure (Case Study in $\backslash$ nEast Tombatu District, South-East Minahasa Regency) \n, " Int. J. Eng. Invent., vol. 3, no. 1, pp. 43-51, 2013, [Online].

Available: http://www.ijeijournal.com/papers/v3i1/G031435 1.pdf.

[11] I. Fahma Nurdina, A. Kustanti, and R. Hilmanto, "Motivation of Farmers in Managing Community Forests in Sukoharjo 1 Village, Sukoharjo District, Pringsewu Regency," J. Sylva Lestari, vol. 3, no. 3, p. 51, 2015, doi: 10.23960 / js13351-62. 